\title{
DAMPAK MASA KERJA, PENGALAMAN KERJA, KEMAMPUAN KERJA TERHADAP KINERJA KARYAWAN
}

\author{
Komang Nonik Jayanti ${ }^{1 *}$ dan Komang Trisna Sari Dewi ${ }^{2 *}$, \\ ${ }^{1,2}$ Sekolah Tinggi Ilmu Ekonomi Satya Dharma Singaraja Bali \\ *Corresponding : nonikjayanti@gmail.com_dan komangtrisnasaridewi@yahoo.com
}

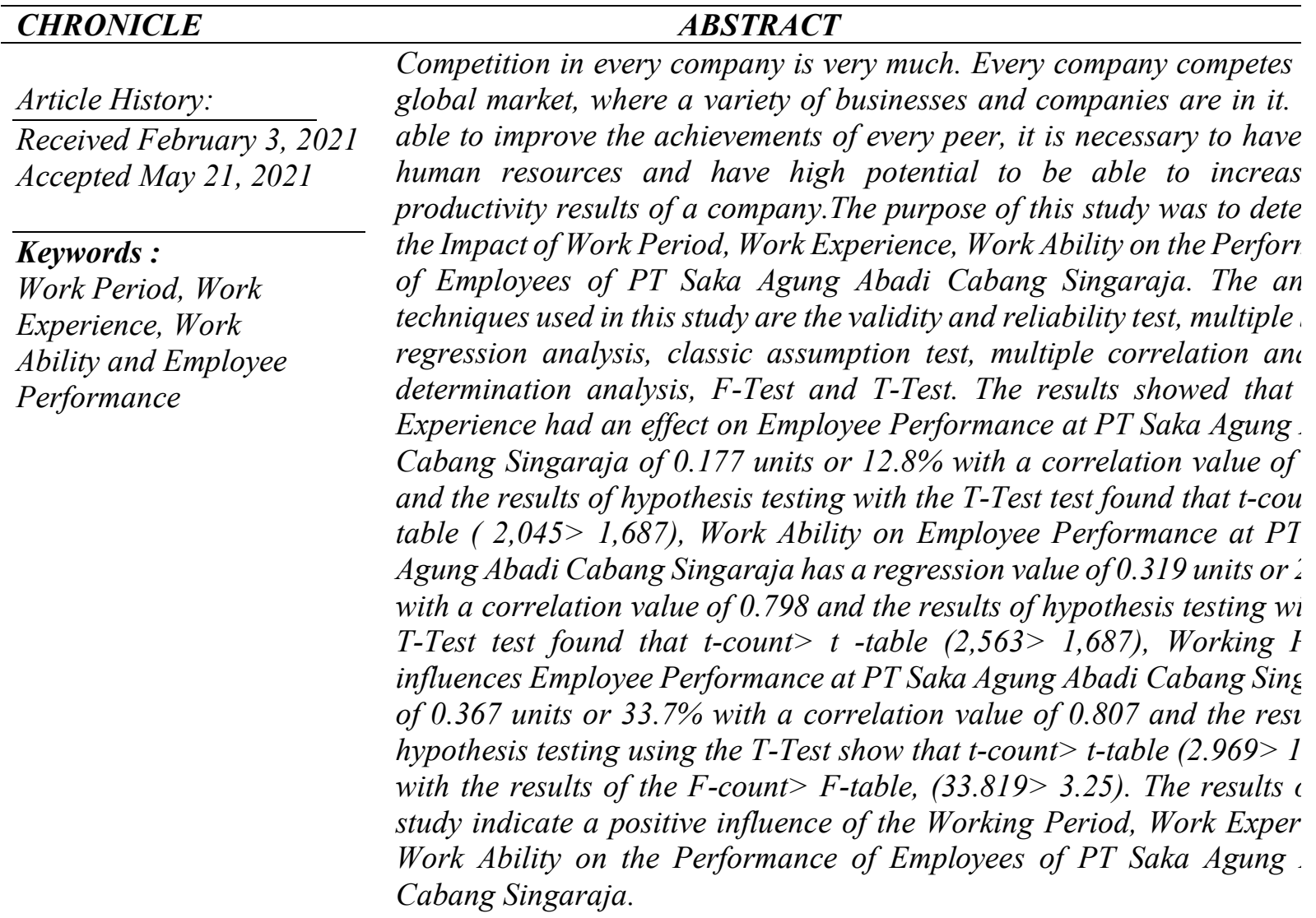

\section{Latar Belakang :}

Di era globalisasi ini persaingan pada setiap perusahaan sangatlah banyak. Setiap perusahaan bersaing pada pasar global, dimana beragam usaha dan perusahaan yang ada didalamnya. Untuk dapat meningkatkan prestasi setiap peerusahaan, maka diperlukannya sumber daya manusia yang baik dan memiliki potensi tinggi untuk dapat meningkatkan hasil produktivitas suatu perusahaan. Menurut Mangkuprawira (2011) sumber daya manusia meruapakan aspek terpenting yang harus dapat dimiliki oleh setiap perusahaan karena tanpa adanya sumber daya manusia maka segala aktivitas yang ada didalam suatu perusahaan tidak dapat berjalan, oleh karenaa itu sumber daya manusia meruapakan aspek terpenting didalam suatu perusahaan. Karena itu setiap pemilik perusahaan harus dapat meningkatkan kinerja yang dimiliki oleh karyawan agar dapat terus berprestasi.

Mengelola sumber daya manusia merupakan hal yang penting dalam mencapai tujuan. Sumber daya manusia juga dapat disebut sebagai personil. Tenaga kerja, pekerja, karyawan, potensi manusiawi sebagai penggerak organisasi dalam proses pembangunan perusahaan,oleh karena itu sumber daya manusia harus dikembangkan dan diarahkan agar tercapainya tujuan organisasi (Nawawi, 2011). Tujuan organisasi tercapai tidak terlepas dari kinerja karyawan dalam perusahaan. Kinerja merupakan suatu kegiatan yang dilakukan untuk melaksanakan, menyelesaikan tugas dan tanggung jawa sesuai dengan harapan dan tujuan yang telah ditetapkan (Septiani, 2015). Karyawan adalah aset bagi 
perusahaan yang sangat berharga yang harus dikelola dengan baik oleh perusahaan agar dapat memberikan kontribusi yang optimal. Jadi kinerja karyawan adalah hasil kerja secara kualitas dan kuantitas yang dicapai oleh seseorang pegawai dalam melaksanakan tugasnya sesuai dengan tanggung jawab yang diberikan. Salah satu hal yang harus menjadi perhatian utama perusahaan adalah dilihat dari masa kerjanya.

Kinerja karyawan sangat ditentukan oleh masa kerja,Masa kerja (length of service) di artikan sebagai lamanya seseorang bekerja. Menurut Siagian (2008) menyatakan bahwa masa kerja menunjukkan beberapa lama seseorang bekerja pada masing-masing pekerjaan atau jabatan. jadi masa kerja ditentukan oleh rentang waktu. masa kerja karyawan ditentukan oleh waktu dimana mereka mulai bekerja sampai sekarang bekerja. Menurut Kreitner dan Kinicki (2004) menyatakan bahwa masa kerja yang lama akan cendrung membuat seseorang pegawai lebih merasa betah dalam suatu organisasi, hal ini disebabkan diantaranya karena telah beradaptasi dengan lingkungan yang cukup lama sehingga seseorang pekerja akan merasa nyaman dengan pekerjaanya. Pernyataan tersebut didukung oleh hasil penelitian yang dilakukan oleh Karima, dkk (2018) dengan hasil penelitiannya menemukan bahwa faktor masa kerja berpengaruh positif dan signifikan terhadap kinerja karyawan.

Peningkatakan kinerja karyawan juga sangat ditentukan oleh kemampuan kerja karyawan. kemampuan merupakan sifat alami yang dimiliki seseorang berupa keterampilan, kesanggupan dan kecerdasan diri seseorang dan melaksanakan pekerjaan atau menyelesaikan tugasnya dengan baik. Menurut Sekartini (2016) kemampuan kerja adalah kapasitas individu untuk melaksanakan berbagai tugas dalam pekerjaan tertentu. Dimana kemampuan individu pada hakekatnya tersususn dari dua faktor yaitu :kemampuan intelektual dan kemampuan fisik. Individu bisa mengerjakan pekerjaannya dengan disesuaikan oleh kemampuan yang ada dalam dirinya dan jenis pekerjaan yang dibebankan kepadanya.Peningkatan kemampuan karyawan pastinya akan meningkatkan kinerja karyawan hal ini sesuai dengan hasil penelitian yang dilakukan oleh Priadana dan Ruswandi (2013) dengan hasil kemampuan karyawan memiliki pengaruh yang positif dan signifikan terhadap kinerja karyawan.

Menurut Nitisemito (2000) "Pengalaman kerja karyawan berhubungan erat dengan kinerja." Pengalaman kerja akan membantu kelancaran didalam menyelesaikan pekerjaan dalam suatu perusahaan Hasil penelitian ini juga mendukung penelitian sebelumnya yang dilakukan oleh Mulya dalam Devischa, dkk (2018) yang menyatakan adanya pengaruh yang signifikan antara Pengalaman Kerja terhadap Kinerja Karyawan, Sedangkan menurut Hitzmam dalam Bili, dkk (2018) pengalaman kerja menunjukkan berapa lama agar pegawai bekerja dengan baik. Disamping itu pengalaman kerja meliputi banyaknya jenis pekerjaan atau jabatan yang pernah di duduki oleh seseorang dan lamanya mereka bekerja pada masing-masing pekerjaan atau jabatan tersebut.

Pentingnya suatu perusahaan untuk meningkatkan kinerja karyawan, mengingat peningkatan kinerja karyawan akan berdampak pada keberhasilan perusahaan. Begitupula halnya dengan PT Saka Agung Abadi Cabang Singaraja yang harus mampu meningkatkan kinerja karyawannya agar mampu bertahan dalam persaingan saat ini. PT Saka Agung Abadi Cabang Singaraja adalah merupakan perusahaan yang bergerak dalam bidang penjualan. Namun dari tahun 2017-2018 dominan mengalami penurunan meski masa kerja,pengalaman kerja dan kemampuan kerja selalu ditingkatkan.

Berdasarkan data diatas dapat dijelaskan bahwa penjualan karyawan PT Saka Agung Abadi Cabang Singaraja selalu mengalami perubahan. Tahun 2017 dominan mengalami penurunan jika dibandingkan dengan bulan sebelumnya, namun Tahun 2018 jumlah penjualan dominan mengalami peningkatan jika dibandingkan dengan bulan sebelumnya. Jika kita melihat perbandingan penjualan pada tahun 2017 dengan tahun 2018 dominan mengalami penurunan. Penurunan terbesar terjadi di bulan Mei yang mengalami penurunan sebesar 31,79\%. Jika dilihat data penjualan pertahunnya yaitu pata haun 2017 bulan Mei pendapatan meningkat sebesar 41,73 namun di tahun 2018 pada bulan Mei jumlah penjualan pengalami penurunan sebesar $24,32 \%$. Dilihat dari peningkatan jumlah penjualan yang paling besar terjadi di bulan November yang mencapai $117,17 \%$ dari tahun sebelumnya. Meski demikian dapat dikatakan bahwa kinerja karyawan ditinjau dari jumlah penjualan belum dapat dikatakan maksimal karena masih dominan jumlah penjualan mengalami penurunan. Jika dilihat dari masa kerja cukup tinggi karena dominan karyawan yang memiliki masa kerja diatas 4 tahun yang mencapai 12 orang atau 32\% dari jumlah keseluruhannya. Seharusnya hal ini bisa menjadi pendorong dalam peningkatan penjualan menunjukkan bahwa setiap karyawan pada perusahaan PT Saka Agung Abadi Cabang Singaraja tersebut sudah memiliki masa kerja yang cukup memadai. Kebutuhan akan 
karyawan yang berkualitas akan meningkat setiap tahunnya. Namun data menunjukkan bahwa jumlah karyawan di PT Saka Agung Abadi Cabang Singaraja jauh lebih dari cukup. Akan tetapi fenomena yang sering terjadi adalah manakala kinerja karyawan yang baik sangat di perlukan baik secara langsung maupun tidak langsung untuk meningkatkan kinerja karyawan. Didasarkan pada kenyataan bahwa seorang pegawai akan membutuhkan serangkaian pengetahuan, keahlian dan kemampuan yang berkembang untuk bekerja dengan baik dan sukses pada posisi yang ditemui selama karirnya, pengembangan sumber daya manusia merupakan hal yang penting dilakukan untuk mengubah sumber daya manusia yang dimiliki organisasi, dari suatu keadaan ke keadaan lain yang lebih baik melalui pendidikan jangka panjang dan pengalaman belajar dalam mempersiapkan pegawai untuk tanggung jawab di masa mendatang, (Simamora, 2004).

\section{Tinjauan Pustaka}

\subsection{Masa Kerja}

Menurut Kreitner dan Kinicki (2004) menyatakan bahwa masa kerja yang lama akan cendrung membuat seseorang pegawai lebih merasa betah dalam suatu organisasi, hal ini disebabkan di antaranya karena telah beradaptasi dengan lingkungan ang cukup lama sehingga seseorang pekerja akan merasa nyaman dengan pekerjaannya. Menurut Handoko (2007) Masa kerja merupakan faktor individu yang berhubungan dengan prilaku dan persepsi individu yang dapat mempengaruhi perkembangan karirnya di perusahaan. Idealnya adalah semakin lama seseorang bekerja maka kemampuan kerjanya akan semakin baik, dan tingkat penguasaan akan pekerjaanya pun semakin fasih.

Sedangkan menurut Siagian (2008) menyatakan bahwa masa kerja menunjukkan beberapa lama seseorang bekerja pada masing-masing pekerjaan atau jabatan. Masa kerja dapat diartikan sebagai sepenggalan waktu yang lama dimana dimana seseorang tenaga kerja masuk dalam satu wilayah tempat tempat usaha sampai batas tertentu (Suma'mur, 2009). Masa kerja adalah suatu kurun waktu atau lamanya tenaga kerja itu bekerja disuatu tempat (Tarwaka, 2010). Masa kerja merupakan salah satu alat yang dapat mempengaruhi kinerja seseorang. Masa kerja juga merupakan faktor yang berkaitan dengan lamanya seseorang bekerja di suatu tempat menurut (Yacob, dkk, 2015).

Menurut Handoko (2007), indikator-indikator yang mempengaruhi masa kerja di antaranya :

1) Tingkat kepuasan kerja

Merupakan bagian dari aspek psikologis yang menggambarkan perasaan seseorang tentang pekerjaannya, rasa puas tercipta dengan adanya kesesuaian antara kemampuan, keterampilan serta harapan tentang pekerjaan yang di hadapi.

2) Stres lingkungan kerja

Sesuatu kondisi ketegangan yang tercipta karena adanya ketidakseimbangan fisik serta psikis yang mempengaruhi emosi, kondisi seseorang dan proses berfikir.

3) Pengembangan karir

Suatu urutan posisi / jabatan yang ditempati seseorang pada masa kehidupan tertentu atau dapat dikatakan juga penempatkan posisi/ jabatan bagian rangkaian dari posisi/ jabatan yang ditempati selama masa kehidupanya.

4) Kompensasi hasil kerja

Seluruh imbalan yang didapatkan oleh karyawan atas hasil kerjanya pada suatu perusahaan . kompensasi dapat berupa fisik ataupun non fisik dan harus dihitung serta diberikan kepada seorang karyawan sesuai dengan pengorbanan yang telah dilakukan kepada perusahaan tempat bekerja.

\subsection{Pengalaman Kerja}

Menurut Nurrofi (2012) pengalaman kerja mengacu pada berapa lama seseorang bekerja, berapa banyak jenis pekerjaan atau jabatan yang pernah dilakukannya dan beberapa periode masa kerjanya pada masing-masing pekerjaan atau jabatan tersebut.Menurut Siagian (2012) pengalaman kerja menunjukan berapa lama pengalaman ang dimiliki agar pegawai bekerja dengan baik. Disamping itu pengalaman kerja meliputi banyaknya jenis pekerjaan atau jabatan yang pernah di duduki oleh seseorang dan lamanya mereka bekerja pada masing-masing pekerjaan atau jabatan tersebut.

Lebih lanjut Trijoko dalam Purwanto dan Hermani (2012) menyatakan bahwa pengalaman kerja adalah pengetahuan atau keterampilan yang telah diketahui dan dikuasai seseorang yang akibat 
dari perbuatan atau pekerjaan yang telah dilakukan selama beberapa waktu tertentu. Menyatakan bahwa Manullang (2012) pengalaman kerja adalah proses pembentukan pengetahuan atau keterampilan tentang metode suatu pekerjaan karen keterlibatan karyawan tersebut dalam pelaksanaan tugas pekerjaan.

Berdasarkan beberapa pengertian pengalaman kerja maka dapat disimpulkan bahwa pengalaman kerja adalah tingkat penguasaan pengetahuan serta keterampilan seseorang dalam tingkat pengetahuan serta keterampilan yang dimiliki. Menurut Nurrofi (2012) indikator yang di gunakan untuk mengukur pengalaman kerja sesesorang adalah sebagai berikut :

1) Waktu.

Lamanya seseorang melaksanakan tugas yang nantinya akan mendapatkan pengalaman kerja yang lebih banyak.

2) Frekuensi.

Semakin sering mengerjakan tugas sejenis maka orang tersebut akan mendapatkan pengalaman kerja yang lebih baik.

3) Jenis tugas.

Semakin meningkat jenis tugas yang dikerjakan seseorang maka orang tersebut akan memperoleh pengalaman kerja yang lebih baik dari sebelumnya.

4) Penerapan .

Penerapan pengetahuan yang semakin banyak maka keterampilan serta sikap seseorang dalam mengerjakan tugas tentunya akan diikuti oleh pengalaman kerja yang meningkatkan.

5) Hasil.

Seseorang yang mempunyai pengalaman kerja yang lebih banyak maka akan mendapatkan hasil pekerjaan yang lebih baik.

\subsection{Kemampuan Kerja}

Menurut Handoko (2001) menjelaskan tentang "kemampuan menjadi faktor penentu keberhasilan dari departemen personalia untuk mempertahankan sumber daya manusia yang efektif'. Individu yang tidak mampu memecahkan masalah yang dihadapinya maka individu akan dianggap tidak bersungguh-sungguh dalam mengerjakan pekerjaan.

Soelaiman (2007) menjelaskan kemampuan kerja adalah "sifat yang di bawa lahir atau di pelajari yang memungkinkan seseorang yang dapat menyelesaikan pekerjaan, baik secara mentap ataupun pisik. Karyawan dalam suatu organisasi, meskipun di motivasi dengan baik, tetapi tidak semua memiliki kemampuan untuk bekerja dengan baik. Kemampuan dan keterampilan memainkan peranan utama dalam prilaku dan kinerja individu. Keterampilan adalah kecakapan yang berhubungan ldengan tugas yang di miliki dan di pergunakan oleh seseorang pada waktu yang tepat".

Kemampuan kerja merupakan kecakapan seseorang yang meliputi kecerdasan dan keterampilan dalam memecahkan persoalan yang dihadapinya. Kemampuan kerja menunjukan kecakapan seseorang seperti kecerdasan dan keterampilan. Kemampuan berhubungan erat dengan kemampuan fisik dan mental ang dimiliki orang untuk melakukan pekerjaan (Raharjo dkk, 2016). Menurut Ramadhan, dkk (2018) " kemampuan kerja adalah kapasitas individu untuk melaksanakan berbagai tugas dalam pekerjaan tertentu. Seluruh kemampuan seseorang individu pada hakekatnya tersusun dari dua perangkat faktor yaitu dari kemampuan intelektual dan fisik

a) Kemampuan intelektual adalah kemampuan ang di perlukan untuk menjalankan kegiatan mental.

b) Kemampuan fisik adalah kemampuan yang di perlukan untuk melaksanakan tugas-tugas yang menurut stamina, kecekakan, kekuatan dan keterampilan serupa

Berdasarkan uraian di atas dapat di simpulkan bahwa kemampuan merupakan sifat alami yang dimiliki seseorang berupa keterampilan, kesanggupan dan kecerdasan diri seseorang dan melaksanakan pekerjaan atau menyelesaikan tugasnya dengan baik.

Menurut Raharjo dkk (2016) indikator yang mempengaruhi kemampuan kerja :

1) Pengetahuan (Knowledge)

Pengetahuan adalah fondasi yang akan membangun keterampilan dan kemampuan seseorang.

Pengetahuan yang terorganisasi akan berdampak pada kinerja yang memadai.

2) Pelatihan (Training)

Pelatihan dengan prosedur sistematis serta terorganisir akan menyebabkan tenaga kerja non 
manajerial mempelajari pengetahuan dan keterampilan teknis untuk tujuan tertentu.

3) Keterampilan (Skill)

Kemampuan seseorang dalam menguasai pekerjaan dan penguasaan alat serta menggunakan mesin tanpa kesulitan.

4) Kesanggupan kerja

Kondisi seorang karyawan yang merasa mampu menyelesaikan pekerjaan yang di berikan.

\section{$2.4 \quad$ Kinerja}

Kinerja karyawan bagi suatu perusahaan merupakan faktor terpenting untuk meningkatkan efisiensi dan efektivitas di dalam perusahaan yang dicerminkan dengan semakin meningkatnya kemampuan perusahaan untuk memperoleh keuntungan atau laba. Oleh karena itu, manajer perusahaan harus benar-benar memperhatikan kinerja dari karyawannya agar dapat mencapai tujuan perusahaan. Veithzal Rivai (2004) mengartikan bahwa "kinerja sebagai hasil kerja yang dihasilkan oleh seorang pegawai dalam satuan waktu tertentu. Pandangan itu menunjukkan bahwa kinerja merupakan hasil karya nyata dari seseorang atau perusahaan yang dapat dilihat, dihitung jumlahnya, dan dapat dicatat waktu perolehannya". Dharma (2007), menyatakan, "kinerja adalah suatu produk atau jasa yang dihasilkan atau diberikan oleh seseorang atau sekelompok orang". Kinerja karyawan dapat dilihat dari hasil kerja yang dicapai, baik berupa produk atau jasa.

Sedangkan menurut pendapat Hariandja (2010), kinerja merupakan hasil kerja yang dihasilkan oleh karyawan sesuai dengan perannya dalam organisasi. Kinerja karyawan merupakan suatu hal yang sangat penting dalam usaha organisasi untuk mencapai tujuannya, sehingga berbagai kegiatan harus dilakukan organisasi untuk meningkatkannya." Sedangkan menurut Dallyodi dan Sudirman (2013), menjelaskan bahwa "kinerja merupakan jumlah hasil yang dicapai oleh seseorang pekerja atau faktor produksi lain dalam jangka waktu tertentu dalam perbandingan jumlah segala biaya dan pengorbanan untuk mewujudkan suatu hasil”.

Pendapat dari para ahli di atas pada hakikatnya memiliki pengertian yang sama, hanya saja penyampaiannya yang berbeda-beda. Berdasarkan pendapat-pendapat para ahli di atas, maka dapat disimpulkan bahwa kinerja karyawan adalah total hasil kerja berupa barang dan jasa yang dihasilkan oleh seorang karyawan pada satuan waktu tertentu. Satuan waktu tertentu bisa satu bulan, satu tahun, bahkan lima tahun atau lebih.

Menurut Dharma (2007), indikator-indikator untuk mempertimbangkan kinerja karyawan yaitu:

1) Kuantitas

Penilaian kinerja karyawan yang dapat diukur dengan kuantitas kerja yang di selesaikan selama waktu tertentu, dengan kuantitas tersebut maka karyawan akan memiliki kemampuan dan kepercayaan untuk melakukan kerja di organisasi.

2) Kualitas

Pengukuran kinerja karyawan dengan melihat kualitas kerja yang dilakukan sesuai dengan yang diharapkan. Penyelesaian juga dapat dilihat dari kecakapan dan juga hasil kerja.

3) Ketepatan waktu

Ketepatan waktu merupakan penyelesaikan pekerjaan sesuai atau tidaknya dengan waktu yang telah direncanakan.

\subsection{Hubungan Antar Variabel}

\section{1) Hubungan Masa Kerja Terhadap Kinerja Karyawan}

Masa kerja menjadi salah satu faktor yang mempengaruhi tingkat kinerja yang di hasilkan karyawan dalam suatu perusahaan, faktor ini dapat meningkatkan kinerja sekaligus dapat menurunkan kinerja karyawan jika tidak diperhatikan secara benar oleh pihak perusahaan. Untuk mengetahui apakah suatu perusahaan mengalami peningkatan hasil produksi atau justru menurun maka perlu di adakan suatu pengukuran terhadap kinerja karyawan (Ravianto, 2011). Menurut Bedjo Siswanto (2011) masa kerja disebut sebagai penyebab meningkat kinerja katyawan karena dengan masa kerja yang lama sudah barang tentu seseorang karyawan akan mendapatkan mutu kerja yang lebih baik dari sebelumnya. Pernyataan tersebut sesuai dengan peneliitian terdahulu yang meneliti hubungan masa kerja terhadap kinerja karyawan yaitu Gumilar dan Setiawan (2018) yang mengatakan bahwa masa kerja berpengaruh 
positif signifikan terhadap kinerja karyawan.

\section{2) Hubungan Pengalaman Kerja Terhadap Kinerja Karyawan}

Pengalama kerja sangat berperan dalam meningkatkan kinerja pegawai. Penelitian terdahulu yang berkaitan dengan teori tersebut adalah yang dilakukan oleh Basuki dalam Bili, dkk (2018) yang menyatakan bahwa ada pengaruh yang Signifikan pengalaman kerja terhadap kinerja karyawan di Kantor Kecamatan Laham Kabupaten Mahakam Ulu. Dengan adanya pengalaman kerja akan memberikan dampak bagi kemampuan karyawan dalam menyelesaikan dan mengerjakan suatu tugas dan tanggung jawab yang diberikan dengan muda karena menurut pengalaman yang mereka punya.

\section{3) Hubungan Kemampuan Kerja Terhadap Kinerja Karyawan}

Peningkatan kemampuan pegawai akan berdampak pada peningaktan kinerja hal ini sudah dibuktikan oleh hasil penelitian Herzberg (2006) yang menjelaskan bahwa semakin meningkatnya kemampuan kerja pegawai maka akan meningkatkan kinerja karyawan. Hal ini sesuai dengan hasil penelitian yang dilakukan Perdana (2012) "Kemampuan menunjukan potensi seseorang untuk melaksanakan tugas dan pekerjaan." Hal ini menjelaskan bahwa untuk melakukan pekerjaan dibutuhkan kemampuan kerja yang baik dan kinerja yang maksimal. Hasil penelitian ini juga mendukung penelitian sebelumnya yang dilakukan oleh Devischa, dkk (2018) yang menyatakan adanya pengaruh yang signifikan antara Kemampuan Kerja terhadap Kinerja Karyawan.

Berdasarkan pemaparan tersebut diatas Peran masa kerja, pengalaman kerja dan kemampuan kerja dapat digambarkan kerangka pemikir sebagai berikut.

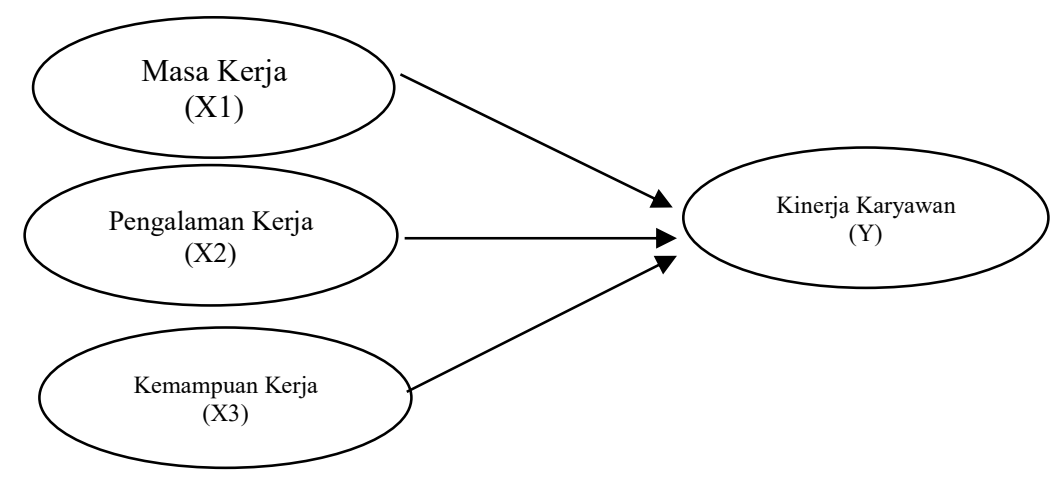

Gambar 1. Kerangka pemikiran

\section{Metode Penelitian}

Desain penelitian yang digunakan adalah tehnik kuantitatif dengan program SPSS 23. Data yang digunakan dalam penelitian ini yaitu data primer yang diperoleh secara langsung dari sumber utama melalui kuesioner dan dokumentasi. Populasi dalam penelitian adalah seluruh jumlah karyawan PT Saka Agung Abadi Cabang Singaraja berjumblah 37 orang sehingga popilasi akan dijadikan sampel mengingat jumlah populasi masih relatif kecil dan masih dalam kemampuan penelitian. Instrumen penelitian yang digunakan dalam penelitian ini diukur kelayakannya dengan uji validitas dan reliabilitas. Tehnik analisis data yang digunakan adalah analisis regresi linier berganda untuk mengetahui pengaruh variabel bebas terhadap variabel terikat secara serempak, dengan rumus sebagai berikut :

$\mathrm{Y}=\mathrm{a}+\mathrm{b}_{1} \mathrm{X}_{1}+\mathrm{b}_{2} \mathrm{X}_{2}+\mathrm{b}_{3} \mathrm{X}_{3}+\varepsilon$

Keterangan :

$\mathrm{Y} \quad=\quad$ Kinerja (variabel terikat)

$\mathrm{a}=$ nilai konstanta

$\mathrm{X}_{1}=$ Masa Kerja (variabel bebas)

$\mathrm{X}_{2}=\quad$ Pengalaman Kerja (variabel bebas)

$\mathrm{X}_{3}=$ Kemampuan Kerja (variabel bebas)

$\mathrm{b}_{1}=$ koefisien regresi Masa Kerja

$\mathrm{b}_{2}=$ koefisien regresi Pengalaman Kerja

$\mathrm{b}_{3}=$ koefisien regresi Kemampuan Kerja

$\varepsilon=$ Eror 


\section{Hasil Penelitian}

Berdasarkan hasil uji validitas berdasarkan angka Corrected Item-Total Correlation menunjukkan nilai lebih besar dari r-tabel sehingga dapat dikatakan instrumen pembentuk variabel valid digunakan. Pengujian reliabilitas dilakukan dengan menggunakan kriteria Cronbach's Alpha lebih besar dari 0,60 sebagai syarat reliabel dan semua instrumen-instrumen pembentuk variabel berada diatas 0,60 sehingga dapat dikatakan reliabel. Uji normalitas data Berdasarkan hasil uji normalitas dengan menggunakan One-Sample Kolmogorov-Smirnov Test menunjukkan bahwa nilai Asymp Sig. (2Tailed) memiliki nilai sebesar 0,634 dimana nilai ini lebih besar dari 5\% $(0,05)$ sehingga dapat disimpulkan bahwa data kuesioner yang digunakan sudah berdistribusi normal. Uji Multikolonieritas dapat dilihat dari nilai tolerance yang berada diatas 0,10 dan nilai VIF dibawah 10 . Hal ini menunjukkan bahwa dalam model regresi tidak terdapat multikolonieritas. Hasil uji Heteroskedastisitas dapat dikatakan bahwa dalam model regresi tidak terdapat masalah heterokedastisitas karena penyebaran titik-titik tersebar secara merata dibawah dan di atas angka nol.

Berdasarkan hasil pengolahan data pada penelitian ini ditentukan persamaan regresi linier berganda sebagai berikut :

$$
\begin{aligned}
& \mathrm{Y}=\mathrm{a}+\mathrm{b}_{1} \mathrm{X}_{1}+\mathrm{b}_{2} \mathrm{X}_{2}+\mathrm{b}_{3} \mathrm{X}_{3}+\varepsilon \\
& \mathrm{KK}=0,681+0,367+0,177+0,319 \\
& \mathrm{KK}=0,681+0,367 \text { (Masa Kerja) }+0,177 \text { (Pengalaman Kerja) }+0,319 \text { (Kemampuan Kerja) }
\end{aligned}
$$

Kinerja karyawan memiliki nilai konstan sebesar 0,681 tanpa dipengaruhi variabel lain. Kinerja karyawan akan meningkat sebesar 0,367 jika perusahaan memperhatikan masa kerja karyawan. Kinerja karyawan akan meningkat sebesar 0,177 jika pengalaman kerja dipertimbangkan dan kinerja karyawan akan meningkat sebesar 0,319 jika kemampuan karyawan di perhatikan. Untuk hasil pengol;lahan data SPSS dapat ditampilkan dalam

\begin{tabular}{|c|c|c|c|c|c|c|}
\hline & \multirow{2}{*}{ Model } & \multicolumn{2}{|c|}{ Unstandardized Coefficients } & \multirow{2}{*}{\begin{tabular}{|c|} 
Standardized Coefficients \\
Beta \\
\end{tabular}} & \multirow[t]{2}{*}{$\mathrm{t}$} & \multirow[t]{2}{*}{ Sig. } \\
\hline & & $B$ & Std. Error & & & \\
\hline \multirow[t]{4}{*}{1} & (Constant) & 0,681 & 0,364 & & 1,869 & 0,070 \\
\hline & MK & 0,367 & 0,123 & 0,417 & 2,969 & 0,006 \\
\hline & LK & 0,177 & 0,087 & 0,210 & 2,045 & 0,049 \\
\hline & KM & 0,319 & 0,124 & 0,364 & 2,563 & 0,015 \\
\hline
\end{tabular}
bentuk tabel sebagai berikut:

Tabel 1. Hasil Analisis Regresi Linier Berganda

\section{1) Hubungan Masa Kerja Terhadap Kinerja Karyawan}

Berdasarkan hasil penelitian pengaruh Masa Kerja berpengaruh terhadap Kinerja Karyawan pada PT Saka Agung Abadi Cabang Singaraja sebesar 0,367 satuan atau sebesar 33,7\% dengan nilai korelasi sebesar 0,807 yang berarti terdapat hubungan berbanding lurus dan sangat kuat antara Masa Kerja dengan Kinerja Karyawan dan hasil pengujian hipotesis dengan uji T-Test didapatkan bahwa thitung $>$ t-tabel $(2,969>1,687)$. Ini menunjukan bahwa Masa Kerja berpengaruh positif signifikan terhadap Kinerja Karyawan, nilai positif disini dilihat dari Unstandardized Coefficients dan signifikan dilihat dari tabel uji T yang nilai T nya lebih kecil dari 0,05. Jadi dapat simpulkan bahwa Masa Kerja pegawai PT Saka Agung Abadi Cabang Singaraja sudah baik yang dibuktikan dengan hasil penelitian ini yang mengatakan berpengaruh positif dan signifikan terhadap Kinerja Karyawan.

Hasil penelitian diatas didukung oleh penelitian yang dilakukan Bedjo Siswanto (2011) masa kerja disebut sebagai penyebab meningkat kinerja katyawan karena dengan masa kerja yang lama sudah barang tentu seseorang karyawan akan mendapatkan mutu kerja yang lebih baik dari sebelumnya. Pernyataan tersebut sesuai dengan peneliitian terdahulu yang meneliti hubungan masa kerja terhadap kinerja karyawan yaitu Gumilar dan Setiawan (2018) yang mengatakan bahwa masa kerja berpengaruh positif signifikan terhadap kinerja karyawan.Dalam hasil penelitian menunjukan bahwa karyawan kebanyakan mengalami kejenuhan dalam bekerja, masih terlihat karyawan yang bermalas-malasan.

\section{2) Hubungan Pengalaman Kerja Terhadap Kinerja Karyawan}

Berdasarkan hasil penelitian pengaruh Pengalaman Kerja berpengaruh terhadap Kinerja Karyawan Pada PT Saka Agung Abadi Cabang Singaraja sebesar 0,177 satuan atau sebesar 12,8\% dengan nilai korelasi sebesar 0,609 yang berarti terdapat pengaruh berbanding lurus dan sangat kuat antara Pengalaman Kerja dengan Kinerja Karyawan dan hasil pengujian hipotesis dengan uji T-Test 
didapatkan bahwa t-hitung $>$ t-tabel $(2,045>1,687)$, ini menunjukkan bawha Pengalaman Kerja memiliki pengaruh yang positif dan signifikan terhadap Kinerja Karyawan, nilai positif disini dilihat dari Unstandardized Coefficients dan signifikan dilihat dari tabel uji T yang nilai T nya lebih kecil dari 0,05. Jadi dapat simpulkan bahwa Pengalaman Kerja PT Saka Agung Abadi Cabang Singaraja baik dalam berkerja ini dibuktikan dengan hasil penelitian ini yang mengatakan berpengaruh positif dan signifikan terhadap Kinerja Karyawan.

Hasil penelitian diatas didukung penelitian yang dilakukan oleh Basuki dalam Bili, dkk (2018) yang menyatakan bahwa ada pengaruh yang Signifikan pengalaman kerja terhadap kinerja karyawan di Kantor Kecamatan Laham Kabupaten Mahakam Ulu. Dengan adanya pengalaman kerja akan memberikan dampak bagi kemampuan karyawan dalam menyelesaikan dan mengerjakan suatu tugas dan tanggung jawab yang diberikan dengan muda karena menurut pengalaman yang mereka punya.

\section{3) Hubungan Kemampuan Kerja Terhadap Kinerja Karyawan}

Berdasarkan hasil penelitian pengaruh Kemampuan Kerja terhadap Kinerja Karyawan pada PT Saka Agung Abadi Cabang Singaraja memiliki nilai regresi sebesar 0,319 satuan atau sebesar 29,0\% dengan nilai korelasi sebesar 0,798 yang berarti terdapat hubungan berbanding lurus dan kuat antara Kemampuan Kerja dengan Kinerja Karyawan dan hasil pengujian hipotesis dengan uji T-Test didapatkan bahwa t-hitung $>$ t-tabel $(2,563>1,687)$, ini menunjukkan bawha Kemampuan Kerja memiliki pengaruh yang positif dan signifikan terhadap Kinerja Karyawan, nilai positif disini dilihat dari Unstandardized Coefficients dan signifikan dilihat dari tabel uji T yang nilai T nya lebih kecil dari 0,05. Jadi dapat simpulkan bahwa Kemampuan Kerja pegawai PT Saka Agung Abadi Cabang Singaraja sudah baik dalam bekerja dengan hasil penelitian ini yang mengatakan berpengaruh positif dan signifikan terhadap Kinerja Karyawan.

Hasil penelitian diatas didukung penelitian yang dilakukan oleh Perdana (2012) "Kemampuan menunjukan potensi seseorang untuk melaksanakan tugas dan pekerjaan." Hal ini menjelaskan bahwa untuk melakukan pekerjaan dibutuhkan kemampuan kerja yang baik dan kinerja yang maksimal. Hasil penelitian ini juga mendukung penelitian sebelumnya yang dilakukan oleh Devischa, dkk (2018) dan Pribadi (2016) yang menyatakan adanya pengaruh yang signifikan antara Kemampuan Kerja terhadap Kinerja Karyawan

\section{KESIMPULAN}

Berkaitan dengan tujuan penelitian yang telah dijelaskan di depan yaitu ingin mengetahui kinerja pegawai pada PT Saka Agung Abadi Cabang Singaraja serta memperhatikan hasil analisis pada, maka dapat disimpulkan bahwa masa kerja, lingkungan kerja, kemampuan kerja berpengaruh positif dan signifikan terhadap kinerja karyawan pada PT Saka Agung Abadi Cabang Singaraja.

\section{Referensi}

Bedjo, Siswanto. (2011). Manajemen Tenaga Kerja Indonesia. Sinar Baru. Bandung.

Bili, Wanceslaus Bili, Erwin Resmawan, dan Daud Kondorura. (2018). Pengaruh Pengalaman Kerja Terhadap Kinerja Pegawai di Kantor Kecamatan Laham Kabupaten Mahakam Ulu. eJournal Pemerintahan Integratif, 6(3), 465-474.

Dallyodi, Mirza dan Iman Sudirman. (2013). Pengaruh Kemampuan Kerja, Motivasi Kerja dan Disiplin Kerja terhadap Kinerja Pagawai Inspektorat Kabupaten Belitung. Jurnal Ekonomi, Bisnis \& Entrepreneurship, 7(1), 10-19.

Devischa, Decky Candra Devischa dan Mochammad Djudi Mukzam. (2018). Pengaruh Pendidikan dan Pengalaman Kerja Terhadap Kemampuan Kerja dan Kinerja Karyawan (Studi Pada Karyawan BRI Syariah Cabang Kediri). Jurnal Administrasi Bisnis Universitas Brawijaya, 65(1), 107-114.

Dharma. (2007). Manajemen Kinerja. Yogyakarta: PT Pustaka Pelajar.

Gumilar, Muhammad Akbar dan H. Heru Setiawan. (2018). Pengaruh Gaji dan Masa Kerja Terhadap Kinerja Karyawan Pada PT. Infomedia Nusantara di Bandung. Perpustakaan Fakultas Ekonomi 
dan Bisnis Unpas Bandung.

Handoko, T.Hani. (2011). Manajemen Sumber Daya Manusia. Yogyakarta: BPFE

Handoko. (2007). Manajemen Personalia Sumber Daya Manusia. Edisi Kedua. Yogyakarta: Penerbit BPFE.

Hariandja. (2010). Manajemen Sumber Daya Manusia, Pengadaan, Pengembangan, Pengkompensasian dan Peningkatan Produktivitas Pegawai. Jakarta: PT Grasindo.

Herzberg. (2006). Teori Motivasi ke Dua. Jakarta: Pustaka Indah.

Karima, A. N., Nursyamsi, I., \& Umar, F. (2018). The Effect of Tthe Work, Training and Motivation to Employee Productivity at PT. Bank Sulselbar Major Branch of Makassar. Hasanuddin Journal of Applied Business and Entrepreneurship, 1(4), 83-95. https://doi.org/10.26487/hjabe.v1i4.133

Kreitner dan Kinicki. 2004. Perilaku Organisasi. Jakarta: Salemba Empat.

Mangkuprawira. (2011). Manajemen Sumber Daya Strategik. Jakarta: Ghalia Indonesia.

Manullang. 2012. Manajemen Personalia. Yogyakarta: Gadjah Mada University Press.

Nawawi. (2011). Manajemen Sumber Daya Manusia Untuk Bisnis Yang Kompetitif. Yogyakarta: Gajah Mada University Press.

Nitisemito. (2000). Manajemen Sumber Daya Manusia dan Organisasi. Jakarta: Ghalia Indonesia.

Nurrofi, Akhmad. (2012). Pengaruh Disiplin Kerja dan Pengalaman Kerja Terhadap Kinerja Karyawan Pada Departemen Produksi PT. Leo Agung Raya Semarang. Jurnal Ilmu Manajemen dan Akuntansi Terapan (JIMAT), 3(1), 1-21.

Perdana, A. (2012). Hubungan Kemampuan Kerja, Kepuasan Kerja, dan Disiplin Kerja Dengan Kinerja Pegawai Kecamatan Kedungliwung Wuni Kabupaten Pekalongan. Universitas Diponegoro. 39.

Priadana, M. S., \& Ruswandi, I. (2013). Pengaruh Kemampuan Kerja dan Motivasi Terhadap Kepuasan Kerja Serta Implikasinya Pada Kinerja Pegawai Dinas Pertambangan dan Energi Provinsi Jawa Barat. Universitas Pasundan Bandung. Jurnal Ekonomi, Bisnis \& Enterpreneurship, 7(2), 52-63.

Purwanto, Vicki Anggraeni, dan Agus Hermani. (2012). Pengaruh Pengalaman Kerja dan Disiplin Kerja Terhadap Kinerja Karyawan CV. Bintang Utama Semarang Bagian Body Repair. Jurnal Ilmu Administrasi Bisnis, 6(2), 19-28.

Raharjo, Slamet, Patricia Dhiana Paramita, dan Moh Mukeri Warso. (2016). Pengaruh Kemampuan Kerja, Pengalaman dan Pelatihan Terhadap Produktivitas Kerja Karyawan Dengan Kompetensi Kerja Sebagai Variabel Intervening (Studi Kasus Pada KUD PATI KOTA Kabupaten Pati. Journal Of Management. 2(2).

Ramadhan, Muhammad Ferryal dan Ari Darmawan Ramadhan. (2018). Pengaruh Kemampuan Kerja, Motivasi, Disiplin Kerja dan Pengembangan Karir Dalam Meningkatkan Kinerja Karyawan PT. Taman Rekreasi Sengkaling. Jurnal Administrasi Bisnis, 61(3), 125-133.

Ravianto. (2011). Manajemen Sumber Daya Manusia. Jakarta: Kencana. Jakarta.

Rivai, Veithzal. (2004). Kepemimpinan dan Perilaku Organisasi. Jakarta: PT Raja Grafindo Persada.

Sekartini, Ni Luh. (2016). Pengaruh Kemampuan Kerja, Disiplin Kerja, Motivasi Kerja Terhadap Kepuasan Kerja dan Kinerja Karyawan Administrasi Universitas Warmadewa. Jurnal Ekonomi dan Bisnis JAGADITHA, 3(2), 64-75. https://doi.org/10.22225/jj.3.2.130.64-75

Septiani, Virgina Maulidiah. (2015). Pengaruh Pelatihan, Pengalaman Kerja, dan Promosi Jabatan Terhadap Kinerja Karyawan Pada Badan Pemeriksa Keuangan Republik Indonesia Perwakilan Sulawesi Utara. Jurnal Emba: Jurnal Riset Ekonomi, Manajemen, Bisnis Dan Akuntansi, 3(3), 992-1002. https://doi.org/10.35794/emba.v3i3.9775 
Siagian. (2008). Manajemen Sumber Daya Manusia. Jakarta: Bumi Aksara.

Simamora. (2004). Manajemen Sumber Daya Manusia. Yogyakarta: STIE YKPN.

Soelaiman. (2007). Manajemen Kinerja; Langkah Efektif Untuk Membangun, Mengendalikan, dan Evaluasi Kerja. Jakarta: PT. Intermedia Personalia Utama.

Suma'mur. (2009). Higiene Perusahaan dan Kesehatan Kerja. Jakarta: Sagung Seto.

Tarwaka. (2010). Manajemen Implementasi K3 di Tempat Kerja. Surakarta: Harapan Press.

Yacob, Desriana M.L, Febi K. Kolibu, dan Maureen I. Punuh. (2015). Hubungan Antara Masa Kerja dan Beban Kerja Dengan Keluhan Low Back Pain Pada Perawat di Ruangan Rawat Inap RS Bhayangkara Tingkat III Manado. Jurnal KESMAS, 7(4). 